\title{
Pemberdayaan Masyarakat Melalui Pengelolaan Sampah Organik Menjadi Pupuk Kompos Oleh Koperasi Sarop Do Mulana Kelurahan Wek II Batangtoru
}

\author{
Maya Indah Lestari \\ Fakultas Dakwah dan Ilmu Komunikasi IAIN Padangsidimpuan \\ (mayaindahlestari@gmail.com)
}

\begin{abstract}
Garbage is one of the causes of environmental pollution, both air pollution, land pollution, and water pollution. Waste problems are not only a problem in various regions, but have become a national problem in Indonesia. This was triggered by increasing population growth and the lack of proper waste management systems. This study included qualitative research using descriptive methods. Research location in Wek II Village, Batangtoru District, South Tapanuli Regency. Data collection techniques through observation, interviews and documentation studies, then in determining the sample the researcher used purposive sampling. The results of this study indicate that the forms of community empowerment through the management of organic waste into compost fertilizer by the Cooperative Sarop Do Mulana are through the provision of facilities in the form of composter baskets to the community for household scale compost fertilizer production and management training. In general, these programs have not met the indicators of empowerment. However, there was a significant change in the level of awareness and willingness to power the people receiving the Composter basket facilities and training. As for the factors that hinder the empowerment efforts in general are the lack of supervision by members of the Sarop Do Mulana Cooperative in Wek II Batangtoru village, lack of understanding to run and maintain the facilities provided and lack of motivation to run the programs that have been provided on an ongoing basis. Keywords: Empowerment, Community, Waste, Organic, Compost.
\end{abstract}

\section{Abstrak}

Sampah merupakan salah satu penyebab terjadinya pencemaran lingkungan, baik pencemaran udara, pencemaran darat, dan pencemaran perairan. Masalah sampah tidak hanya menjadi masalah di berbagai daerah, tetapi sudah menjadi masalah nasional di Indonesia. Hal tersebut dipicu oleh pertambahan jumlah penduduk yang semakin tinggi dan minimnya sistem pengelolaan sampah yang tepat. Penelitian ini termasuk penelitian kualitatif dengan menggunakan metode deskriptif. Lokasi penelitian di Kelurahan Wek II, Kecamatan Batangtoru, Kabupaten Tapanuli Selatan. Teknik pengumpulan data melalui observasi, wawancara dan studi dokumentasi, kemudian dalam menentukan sampel peneliti menggunakan purposive sampling. Hasil penelitian ini menunjukkan bahwa bentuk-bentuk pemberdayaan masyarakat melalui pengelolaan sampah organik menjadi pupuk kompos oleh Koperasi Sarop Do Mulana adalah melalui pemberian fasilitas berupa keranjang komposter kepada masyarakat untuk produksi pupuk kompos skala rumah tangga beserta pelatihan pengelolaannya. Program-program tersebut secara umum belum memenuhi indikator keberdayaan. Namun terdapat perubahan yang signifikan dalam tingkat kesadaran dan kemauan untuk berubah (power to) masyarakat 
penerima fasilitas keranjang komposter dan pelatihannya. Adapun faktor-faktor yang menghambat upaya pemberdayaan tersebut secara umum adalah kurangnya pengawasan oleh anggota Koperasi Sarop Do Mulana kelurahan Wek II Batangtoru, kurangnya pemahaman untuk menjalankan dan memelihara fasilitas yang disediakan dan kurangnya motivasi untuk menjalankan program yang telah diberikan secara berkelanjutan.

Kata Kunci: Pemberdayaan, Masyarakat, Sampah, Organik, Kompos

\section{A. Pendahuluan}

Sampah merupakan konsekuensi dari seluruh aktifitas manusia. Menurut American Public Health Association, sampah (waste) diartikan sebagai sesuatu yang tidak digunakan, tidak terpakai, tidak disenangi atau sesuatu yang dibuang, yang berasal dari kegiatan manusia dan tidak terjadi dengan sendirinya. ${ }^{1}$ Sampah dapat membawa dampak yang sangat buruk bagi kesehatan masyarakat apabila tidak ditanggulangi. Jika sampah dibuang sembarangan atau ditumpuk tanpa adanya pengelolaan yang baik, maka akan menimbulkan berbagai macam masalah kesehatan yang terjadi di lingkungan masyarakat. Sampah termasuk salah satu masalah yang sulit dipecahkan. Semakin bertambahnya penduduk, sampah yang dihasilkan juga semakin bertambah. Selain itu, pesatnya pembangunan di suatu daerah, akan mendatangkan pengaruh timbal balik terhadap daerah tersebut termasuk dalam masalah kesehatan lingkungan yang disebabkan oleh sampah. ${ }^{2}$ Dirjen Pengelolaan Sampah, Limbah dan B3 Kementrian Lingkungan Hidup dan Kehutanan (KLHK) Tuti Hendrawati Mintarsih menyebutkan bahwa pada tahun 2016 ada sekitar 65 juta ton sampah per harinya yang diproduksi masyarakat Indonesia. ${ }^{3}$ Jumlah tersebut naik satu ton dibandingkan produksi 2015 sekitar 64 juta ton sampah per hari. Tuti juga menuturkan bahwa total jumlah sampah Indonesia di 2019 akan mencapai 68 juta ton dan sampah plastik diperkirakan mencapai 9,25 juta ton. ${ }^{4}$ Komposisi sampah tersebut terdiri dari 60 persen organik dan 14 persen sampah plastik dari total sampah yang ada. ${ }^{5}$

Permasalahan sampah di kota besar maupun kecil hampir sama. Begitu juga di wilayah pedesaan atau kelurahan. Seiring dengan pertambahan penduduk, sampah yang dihasilkan juga semakin bertambah dan beragam. Kecamatan Batangtoru sebagai bagian dari Kabupaten Tapanuli Selatan adalah kecamatan yang selalu mengalami peningkatan jumlah penduduk setiap tahunnya. Pernyataan ini dikuatkan oleh data dari Badan Pusat Statistik Tapanuli Selatan. Berdasarkan tingkat pertumbuhan penduduk tahun 2016, Kecamatan Batang Toru merupakan kecamatan yang memiliki tingkat pertumbuhan terbesar di Kabupaten Tapanuli Selatan dengan nilai 1, 678\%. ${ }^{6}$

Peningkatan jumlah penduduk di Kecamatan Batangtoru berbanding lurus dengan tingkat produksi sampah yang dihasilkan setiap harinya. Kecamatan Batangtoru tergolong salah satu wilayah di Kabupaten Tapanuli Selatan dengan produksi sampah

\footnotetext{
${ }^{1}$ Arif Sumantri, Kesehatan Lingkungan, (Jakarta: Kencana Prenada Media Group, 2010), hlm. 62

${ }^{2}$ Slamet Ryadi, Kesehatan Lingkungan, (Surabaya: Karya Anda, 1984), hlm. 9

http://nasional.republika.co.id/berita/nasional/daerah/17/03/15/omv2sg319-setiap-hariindonesia-produksi-sampah-65-juta-ton, diakses tgl. 13 Januari 2018

${ }^{4}$ Ibid.

${ }^{5}$ Ibid.

${ }^{6}$ Ibid.
} 
yang tinggi. Berdasarkan data yang diambil dari dokumen Strategi Sanitasi Kabupaten Tapanuli Selatan Tahun 2017-2021, total sampah yang dihasilkan masyarakat Kecamatan Batangtoru setiap harinya adalah 96, $23 \mathrm{~m}^{3}$.

Peningkatan pertumbuhan penduduk dan produksi sampah di Kecamatan Batangtoru berbanding terbalik dengan tingkat kesadaran masyarakat dalam mengelola sampah rumah tangganya sendiri. Kesadaran masyarakat Batangtoru dalam mengelola dan memanfaatkan sampah dinilai masih kurang. Sekitar 57\% sampah masyarakat tidak terangkut ke Tempat Pembuangan Akhir. ${ }^{8}$

Masyarakat masih banyak yang mengelola sampahnya secara tradisional yaitu dengan membakar dan menimbun sampah, serta ada juga yang membuang sampah ke Sungai Batangtoru dan selokan. Masyarakat terbiasa melakukan suatu tindakan yang dirasa mudah untuk dilakukan. Tempat yang kotor dan memang sudah banyak sampahnya, bisa membuat orang yakin bahwa membuang sampah sembarangan diperbolehkan di tempat tersebut. Jadi, warga sekitar tanpa ragu untuk membuang sampahnya di tempat tersebut. ${ }^{9}$ Masyarakat kurang mengetahui akibat dari kebiasaan membuang sampah tersebut terhadap lingkungan dan kesehatan. Namun, sebenarnya jika mereka mengetahui bahwa sampah mempunyai nilai guna maka tentunya banyak sekali dampak positif sampah dalam kehidupan sehari-hari baik bagi kesehatan, keindahan, maupun dari segi ekonomi.

Pemberdayaan masyarakat melalui pengelolaan sampah menjadi pupuk organik di Batangtoru telah ada sejak tahun 2016 dengan berbasis komunitas. Komunitas tersebut diberi nama CO-MAPRO (Komunitas Mandiri Produktif). Nama "CO-MAPRO” sendiri merupakan hasil rumusan dari para pemuda Kelurahan Wek II Batangtoru. ${ }^{10}$ Ketua Koperasi Sarop Do Mulana, Okto Anggara, mengatakan bahwa:

Berdasarkan pengamatan peneliti, telah banyak manfaat yang didapatkan masyarakat Batangtoru dengan adanya kegiatan ini, di antaranya dapat memberikan income tambahan kepada masyarakat khususnya anggota koperasi. Koperasi Sarop Do Mulana ini juga memiliki beberapa program pemberdayaan masyarakat, di antaranya adalah pemberian fasilitas berupa keranjang komposter bagi masyarakat dan pelatihannya, pelatihan penanaman sistem aquaponik, hidroponik, pelatihan sawah organik dan lainnya. ${ }^{11}$ Dari program-program ini diharapkan paradigma masyarakat yang menganggap sampah sebagai barang yang tidak berguna dapat berubah dan mulai tergerak memproduksi pupuk secara mandiri serta menjadi lebih kreatif dalam bertani.

Penulis tertarik melakukan penelitian terhadap pemberdayaan masyarakat melalui pengelolaan sampah organik di Batangtoru oleh Koperasi Sarop Do Mulana sebab badan ini merupakan wujud kesadaran dan kemandirian masyarakat untuk mengembangkan potensi Kecamatan Batangtoru. Penetapan Batangtoru sebagai Pusat Kegiatan Lokal (PKL) Tapanuli Selatan menjadi alasan kuat penulis untuk mengangkat penelitian dengan judul, "Pemberdayaan Masyarakat melalui Pengelolaan Sampah

\footnotetext{
${ }^{7}$ http://ppsp.nawasis.info/dokumen/perencanaan/sanitasi/pokja/ssk/kab.tapanuliselatan/D ok.Final\%20SSK.pdf, diakses tgl. 15 Januari 2018

${ }^{8}$ http://ppsp.nawasis.info/dokumen/perencanaan/sanitasi/pokja/ssk/kab.tapanuliselatan/D ok.Final\%20SSK.pdf, diakses tgl. 15 Januari 2018

${ }^{9}$ Hasil Observasi peneliti selama tinggal di Kecamatan Batangtoru dari tahun 2008 sampai 2018

${ }^{10}$ Okto Anggara, Ketua Koperasi Sarop Do, Wawancara, tgl. 10 Januari 2017 pukul 21.00 WIB

${ }_{11}$ Okto Anggara, Ketua Koperasi Sarop Do Mulana, Wawancara, tgl. 10 Januari 2017 pukul 21.00 WIB.
} 
Organik menjadi Pupuk Kompos oleh Koperasi Sarop Do Mulana Kelurahan Wek II Batangtoru".

\section{B. Landasan Teoritis}

\section{Pengertian Pemberdayaan Masyarakat}

Pemberdayaan dapat dimaknai sebagai suatu proses menuju berdaya, proses memperoleh daya, atau proses pemberian daya dari pihak yang memiliki daya kepada pihak yang kurang atau belum berdaya. ${ }^{12}$ Pengertian "proses" menunjuk pada serangkaian tindakan atau langkah-langkah yang dilakukan secara kronologis-sistematis yang mencerminkan tahapan upaya mengubah masyarakat yang kurang atau belum berdaya menuju keberdayaan. Pemberdayaan masyarakat tidak sekedar pemberian dari pihak yang memiliki sesuatu kepada pihak yang tidak memiliki melainkan adanya transfer pengetahuan kepada masyarakat. ${ }^{13}$

Menurut David C. Korten, sebagaimana yang dikutip oleh Soetomo, memahami power tidak cukup dari dimensi distributif akan tetapi juga dari dimensi generatif. ${ }^{14}$ Dalam dimensi distributif, berdasarkan terminologi personal, power dapat diartikan sebagai kemampuan seseorang untuk mempengaruhi orang lain. Menurut pendapatnya, sebagai dasar pemahaman pengertian pemberdayaan dalam pembangunan, power dalam dimensi generatif justru lebih penting. Suatu kelompok hanya akan memperoleh tambahan atau peningkatan power dengan mengurangi power kelompok lain. Kelompok yang bersifat powerless akan memperoleh tambahan power atau empowerment, hanya dengan mengurangi power yang ada pada kelompok powerholders. ${ }^{15}$

Jim Ife dalam bukunya Community Development sebagaimana yang dikutip oleh Tatan Hermansyah, dkk menyatakan pengertian pemberdayaan adalah sebagai berikut: "Empowerment means providing people with the resorces, opportunities, knowledge and skills to increase their capacity to determine their own future, and participate in and affect the life of their community." 16 Dari pengertian tersebut dapat diambil pemahaman bahwa pemberdayaan berarti memberikan sumberdaya, kesempatan, pengetahuan dan keterampilan kepada warga untuk meningkatkan kemampuan mereka dalam menentukan masa depannya sendiri dan berpartisipasi dalam dan memengaruhi kehidupan dari masyarakatnya.

World Bank mengartikan pemberdayaan sebagai upaya untuk memberikan kesempatan dan kemampuan kepada kelompok masyarakat (miskin) untuk mampu dan berani bersuara (voice) atau menyuarakan pendapat, ide, atau gagasan-gagasannya, serta kemampuan dan keberanian untuk memilih (choice) sesuatu (konsep, metode, produk, tindakan, dll) yang terbaik bagi pribadi, keluarga dan masyarakatnya. Dengan kata lain, pemberdayaan masyarakat merupakan proses meningkatkan kemampuan dan sikap kemandirian masyarakat. ${ }^{17}$

\footnotetext{
12 Sulistiyani dan Ambar Teguh, Kemitraan dan Model-Model Pemberdayaan (Yogyakarta: Gava Media, 2004), hlm. 10

${ }^{13}$ Icol Dianto, "PEMBERDAYAAN KELOMPOK USAHA PENINGKATAN PENDAPATAN KELUARGA SEJAHTERA (UPPKS) DALAM MENINGKATKAN KESEJAHTERAAN KELUARGA DI PASAMAN," Jurnal Hikmah 10, no. 1 (2016), hlm. 123.

${ }^{14}$ Soetomo, Pemberdayaan Masyarakat, Mungkinkah Muncul Antitesisnya? (Yogyakarta: Pustaka Pelajar, 2011), hlm. 88

${ }^{15}$ Ibid., hlm. 89

16 Tatan Hermansah, dkk, Dasar-dasar Pengembangan Masyarakat Islam (Jakarta: Fakultas IImu Dakwah dan Komunikasi UIN Syarif Hidayatullah, 2009), hlm. 29 hlm. 117

${ }_{17}$ Aprillia Theresia, dkk., Pembangunan Berbasis Masyarakat (Bandung: Alfabeta, 2014),
} 
Dari beberapa defenisi tersebut dapat diambil pemahaman bahwa pemberdayaan merupakan suatu proses yang ditempuh dalam mengupayakan kesejahteraan masyarakat dengan menjamin keamanan dan hak asasi manusia demi terwujudnya masyarakat yang partisipatif dan mandiri. Pendekatan utama dalam konsep pemberdayaan masyarakat adalah bahwa masyarakat tidak hanya dijadikan sebagai objek pembangunan, tetapi juga merupakan subjek dari upaya pembangunan itu sendiri. Sebagai subjek dan objek pembangunan, pemberdayaan menyentuh segala aspek kehidupan manusia. Pengertian pemberdayaan pun meluas jika dikaitkan dengan berbagai bidang kehidupan, diantaranya pemberdayaan dalam bidang pendidikan, pemberdayaan dalam bidang kesehatan, pemberdayaan dalam bidang sosial politik dan pemberdayaan dalam perspektif lingkungan.

Pemberdayaan masyarakat melalui pengelolaan sampah organik menjadi pupuk kompos oleh Koperasi Sarop Do Mulana di Kelurahan Wek II Batangtoru merupakan integrasi pemberdayaan masyarakat berbasis lingkungan dan ekonomi. Pemberdayaan ini dimaksudkan agar setiap individu memiliki kesadaran, kemampuan, dan kepedulian untuk mengamankan dan melestarikan lingkungan dan pengelolaannya secara berkelanjutan. Namun dari pengelolaan sampah organik tersebut juga dapat menghasilkan manfaat materil bagi masyarakat..

\section{Indikator Pemberdayaan Masyarakat}

Pemberdayaan sebagai suatu program dapat dilihat dari tahapan-tahapan guna mencapai tujuan yang sudah ditentukan jangka waktunya. Tahapan-tahapan tersebut dilaksanakan berdasarkan indikator-indikator tertentu. Kajian-kajian konseptual tentang pemberdayaan menyajikan banyak indikator. Salah satunya adalah pendapat dari Edi Suharto yang menyatakan beberapa indikator pemberdayaan, yaitu:

a. Tingkat kesadaran dan keinginan untuk berubah (power to)

b. Tingkat kemampuan meningkatkan kapasitas untuk memperoleh akses (power within)

c. Tingkat kemampuan menghadapi hambatan (power over)

d. Tingkat kemampuan kerjasama dan solidaritas (power with) ${ }^{18}$

Konsep pemberdayaan masyarakat menetapkan kaidah bahwa program pemberdayaan masyakat baru bisa dianggap berhasil ketika ia mampu mewujudkan power with pada kelompok sasaran. Namun demikian, parameter-parameter lainnya meskipun tingkatannya lebih rendah dianggap sebagai entry-point untuk mewujudkan Tingkat Keberdayaan Masyarakat. Parameter ini menggambarkan kondisi ketika kelompok sasaran pemberdayaan mampu mengembangkan potensi keberdayaannya sendiri (parameter 1-3), tetapi juga mampu memberdayakan orang/keluarga lain di komunitasnya. ${ }^{19}$

\section{Pengelolaan Sampah Menjadi Pupuk Kompos}

Pengelolaan sampah adalah kegiatan yang sistematis, menyeluruh, dan berkesinambungan yang meliputi pengurangan dan penanganan sampah. ${ }^{20}$ Kegiatan tersebut merupakan kewajiban bersama masyarakat maupun pemeritahan. Ada dua

${ }^{18}$ Edi Suharto dalam Hairi Firmansyah, "Ketercapaian Indikator Keberdayaan Masyarakat dalam Program Pemberdayaan Fakir Miskin (P2FM) di kota Banjarmasin", Jurnal Agribisnis Perdesaan Vol. 2, No.2, Juni 2012, hlm. 174

19 Ibid.

${ }^{20} \mathrm{https}$ ://www.slideshare.net/metrosanita/undangundang-no-18-tahun-2008-tentangpengelolaansampah, diakses tgl. 13 Januari 2018. 
bentuk alternatif untuk megelola sampah, yaitu dengan cara tidak membakar dan usaha yang membutuhkan kepedulian masyarakat.

Berikut ini beberapa aternatif pengelolaan sampah yang biasa dilakukan masyarakat:

a) Penumpukan

Metode ini tidak memusnahkan secara langsung, namun membiarkan sampah membusuk mejadi bahan organik. Hal tersebut beresiko menjadi sumber penyakit dan menyebabkan pecemaran.

b) Pembakaran

Pembakaran merupakan metode yang paling sering dilakukan oleh masyarakat. Hanya saja, cara ini sebaiknya dilakukan untuk sampah yang dapat terbakar habis dan dilakukan di tempat yang lokasinya jauh dari pemukiman. Sebab, pembakaran sampah dapat menghasilkan dioksin, yaitu ratusan jenis senyawa kimia berbahaya.

c) Sanitary Landfill

Metode ini khusus digunakan sebagai tempat pembuangan akhir ketika lahan yang disediakan telah penuh terisi sampah. Caranya dengan membuat cekungan baru untuk mengubur sampah yang diatasnya ditutupi tanah.

d) Pengomposan

Pengomposan merupakan langkah sederhana yang tidak menimbulkan efek samping bagi lingkungan, tetapi memberi nilai tambah bagi sampah khususnya sampah organik. ${ }^{21}$

Pengelolaan sampah harus memperhatikan teknis pengelolaan dan sosial budaya masyarakat. Membudayakan hidup bersih dan tertib menjadi kunci penyelesaian masalah sampah. Berikut empat langkah pengelolaan sampah yang membutuhkan kepedulian masyarakat:

a) Reduce (mengurangi), yaitu meminimalisasi barang atau material yang digunakan.

b) Reuse (memakai kembali), yaitu mengusahakan menghindari peggunaan barangbarang yang hanya bisa sekali pakai.

c) Recycle (mendaur ulang), yaitu memanfaatkan sampah menjadi barang baru yang lebih berguna.

d) Replace (mengganti), yaitu mengganti barang-barang sekali pakai dengan barang yang lebih tahan lama. Contohnya menggati kantong kresek dengan keranjang saat berbelanja. $^{22}$

Pengelolaan sampah dengan cara pengomposan atau mengubahnya mmenjadi pupuk merupakan alternatif terbaik. Ada beberapa metode pembuatan kompos, antara lain:

1. Secara alami

Proses pembuatan kompos secara alami dapat dilakukan baik secara tradisional (anaerobik) maupun secara sederhana (aerobik). Metode tradisional banyak digunakan oleh petani. Pada metode ini, bahan organik dihancurkan tanpa bantuan udara, yaitu degan meletakkan tumpukan sampah di dalam lubang tanpa udara di tanah dan dibiarkan beberapa saat. Pembuatan kompos dengan metode ini memerlukan waktu yang lama untuk mendapatkan kompos, selain dapat menimbulkan bau akibat pembentukan gas H2S dan NH3. Pembuatan kompos dengan metode sederhana dilakukan degan cara mengaduk atau membolak-balikkan

${ }^{21}$ Sukamto Hadisuwito, Op.Cit., hlm. 5-7

${ }^{22}$ Arif Sumantri, Op.Cit., hlm. 74 
sampah atau dengan menambahkan nutrien yang berupa lumpur atau kotoran binatang ke dalam sampah. ${ }^{23}$

2. Mekanis

Pembuatan kompos secara mekanis dilakukan di pabrik untuk menghasilkan kompos dalam waktu singkat. Sampah organik yang telah dipisahkan degan sampah anorganik (karet, plastik, logam) dipotong kecil-kecil dengan alat pemotong. Potongan sampah tersebut kemudian dimasukkan ke dalam digester stabilizator agar terjadi dekomposisi. Dalam digester ini perlu dilakukan pengaturan suhu, udara, dan pengadukan sampah. Setelah 3-5 hari, kompos sudah dapat dihasilkan dan ke dalamnya dapat pula dialiri bahan zat kimia tertentu untuk keperluan tanaman (misal karbon, nitrogen, fosfor, sulfur dan sebagainya). ${ }^{24}$

\section{Pengelolaan Sampah Dalam Perspektif Islam}

Sampah merupakan sisa-sisa kehidupan manusia yang tidak terpakai lagi dan terbuang ke lingkungan. Islam mempunyai pandangan sendiri dalam upaya penanggulangan sampah. Dalam Al-Qur'an atau Hadis memang tidak dijelaskan secara gamblang tentang sampah dan pengelolaannya. Akan tetapi terdapat beberapa riwayat yang menggambarkan betapa Islam mengajarkan pemeluknya agar mengelola sampah. Dalam sebuah hadits shahih Rasulullah Șallallahu 'alaihi wa sallam bersabda :

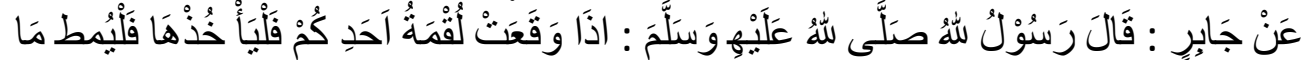

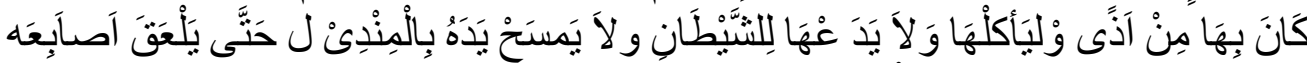

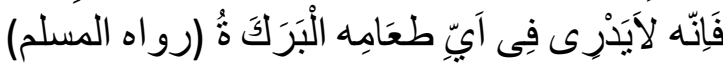

Artinya: "Dari Jabir bin Abdillah radhiyallahu 'anhu, Rasulullah Shallallahu 'alaihi wasallam bersabda Jika makanan salah satu kalian jatuh maka hendaklah diambil dan disingkirkan kotoran yang melekat padanya, kemudian hendaknya di makan dan jangan dibiarkan untuk setan"25

Pada hadis tersebut, sedikit makanan terjatuh yang berpotensi menjadi sampah dianjurkan untuk diambil, dibersihkan kemudian dimakan. Dari hadis ini dapat diambil sebuah anjuran pengelolaan sampah dalam skala yang lebih besar. Sampah rumah tangga sehari-hari yang awalnya berpotensi menjadi penyebab pencemaran lingkungan di halaman ataupun sekitar rumah warga, akan lebih memberikan manfaat jika dikelola dengan cara yang tepat. Salah satunya adalah dengan mengelola sampah tersebut menjadi pupuk kompos yang bermanfaat bagi tanaman.

Salah satu dampak positif dari kegiatan pengolahan sampah rumah tangga yaitu menciptakan kesejahteraan lingkungan. Islam telah mengajarkan kepada ummatnya agar senantiasa menjaga kelestarian alam. Dimana kelestarian alam ini merupakan bagian dari ajaran islam yaitu syukur. Karena Allah menciptakan alam semesta ini tidak lain hanya untuk memenuhi kebutuhan manusia, oleh karenanya manusia perlu menjaga kelestarian alam ini dengan tidak mengotorinya, tidak merusak dan semacamnya. Sebagaimana Rasulullah Șhallallahu 'alaihi wa sallam bersabda:

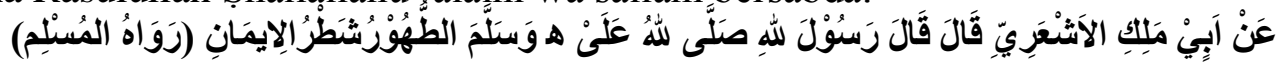

${ }^{23}$ Ibid., hlm. 76

24 Riswan, Henna Rya Sunoko dan Agus Haadiyarto, "Pengelolaan Sampah Rumah Tangga Di Kecamatan Daha Selatan" Jurnal Ilmu Lingkungan Vol.9, No. 1, April 201, hlm. 3334

25 Ibnu Abbas, Pandangan Syariah Dalam Pengelolaan Sampah, https://ibnuabbaskendari.wordpress.com/2011/02/20/pandangan-syariah-dalam pengelolaan asampah. html 
Artinya: "Dari Malik Al Asy`ari dia berkata, Rasulullah saw. Bersabda kebersihan itu adalah separuh dari" (HR. Muslim). ${ }^{26}$

Hadis diatas memberikan petunjuk bahwa kebersihan itu bersumber dari iman dan merupakan bagian dari iman. Dengan demikian kebersihan dalam ajaran Islam merupakan aspek ibadah dan aspek moral, dan karna itu sering juga dipakai kata bersuci sebagai kata paduan dengan kata membersihkan atau melakukan kebersihan. Ajaran kebersihan tidak hanya merupakan slogan atau teori belaka, tetapi harus dijadikan pola hidup praktis, yang mendidik manusia hidup bersih sepanjang masa.

\section{Pembahasan}

\section{Bentuk-bentuk Pemberdayaan melalui Pengelolaan Sampah Organik menjadi Pupuk Kompos}

Koperasi Sarop Do Mulana merupakan sebuah lembaga kemasyarakatan yang bergerak dibidang pemberdayaan lingkungan dan ekonomi. Sebagai pusat pengelolaan sampah organik menjadi pupuk kompos, Koperasi Sarop Do Mulana telah menjadi pelaku perubahan (change agent) di lingkungan Masyarakat Batangtoru. Sampah masyarakat dan sampah dari Pasar Batangtoru yang awalnya tidak berguna dan dibuang saja ke Tempat Pembuangan Sampah Sementara di Aek Sirara kini bisa di kelola menjadi Pupuk Kompos yang memiliki daya jual. Pupuk tersebut menjadi sumber utama penghasilan koperasi yang dijual ke berbagai instansi dan perusahaan. Koperasi Sarop Do Mulana berperan sebagai fasilitator, animasi sosial dan edukator bagi masyarakat Batangtoru dalam mengelola sampah. Sebagai fasilitator dan animasi sosial koperasi ini memunculkan energi, inspirasi dan antusiasme masyarakat dalam mengelola potensi yang ada di masyarakat. Sebagai edukator, koperasi ini membangkitkan kesadaran masyarakat untuk memanfaatkan potensi tersebut dan mengembangkannya.

Untuk itu, Koperasi Sarop Do Mulana membuat beberapa program yang dilakukan untuk menyebarkan pengetahuan dan keterampilan dalam mengelola sampah rumah tangga dan memanfaatkan pekarangan menjadi lahan pertanian fungsional. Program tersebut atara lain yaitu pemberian fasilitas berupa keranjang komposter untuk produksi pupuk kompos skala rumah tangga. Komposter adalah suatu alat yang digunakan untuk membuat kompos. Komposter dibuat dengan tujuan membantu bakteri pengurai (dekomposer) mempercepat proses penguraian bahan organik menjadi pupuk organik (kompos), baik berbentuk cair maupun padat. ${ }^{27}$ Banyak media yang dapat digunakan sebagai wadah komposter, misalnya ember besar, tong, karung goni dan keranjang. Pada umumnya istilah komposter digunakan dalam pembuatan pupuk organik skala kecil seperti skala rumah tangga.

Pembagian keranjang komposter oleh Koperasi Sarop Do Mulana dilakukan pada bulan 17 November 2017 seiring dengan adanya program KRPL (Kawasan Rumah Pangan Lestari) dan Zona Emas oleh PT. Agincourt Resources. Pembagian keranjang komposter ini merupakan salah satu program pemberdayaan yang sekali dilakukan oleh Koperasi Sarop Do Mulana dengan tujuan untuk mengubah paradigma masyarakat

${ }^{26}$ Abi Husen Muslim al-Hajaj al-Qusyairi al-Naisabury, Shahǐh Muslim, Juz I, (Bairut: Dar al- Fikr, 1992), hlm. 203

${ }^{27}$ Hery Soerkoyo, Kiat Pintar Memproduksi Kompos dengan Pengurai Buatan Sendiri (Yogyakarta: Lily Publisher, 2011), Hlm. 16 
Kelurahan Wek II Batangtoru tentang sampah. ${ }^{28}$ Koperasi Sarop Do Mulana memberikan motivasi kepada masyarakat melalui pemberian keranjang komposter dan pelatihan kepada masyarakat agar masyarakat mampu memproduksi pupuk sendiri dari limbah rumah tangga. Keberlajutan dari program ini diharapkan masyarakat mampu memproduksi pupuk dari sampah rumah tangga sendiri, bahkan mampu menjualnya ke pihak lain termasuk kepada Koperasi Sarop Do Mulana Sendiri, sehingga hal tersebut mejadi penambah pendapatan rumah tangga. Pupuk kompos tersebut dapat dipergunakan untuk kesuburan tanaman-tanaman di pekarangan rumah.

Okto Anggara menyampaikan bahwa pupuk kompos merupakan pupuk yang sangat bagus untuk kesuburan tanah. Berbeda dengan pupuk kimia, yang pada dosis tertentu akan menghilangkan unsur hara pada tanaman. Pupuk kompos apabila diberikan secara rutin, maka unsur hara tanah akan meningkat, sehingga pada kurun waktu tertentu tanah tidak lagi membutuhkan pupuk. ${ }^{29}$

Keranjang komposter ini merupakan bentuk mini dari produksi pupuk kompos melalui pengelolaan sampah di Koperasi Sarop Do Mulana. Pengolahannya mengadopsi sistem Kompos Takakura. Takakura adalah kompos yang diperkenalkan oleh Pak Takakura seorang peneliti dari Jepang yang melakukan penelitiannya tentang pembuatan kompos secara praktis, di Surabaya bersama PUSDAKOTA, Universitas Surabaya dan Kitakyushu Techno-cooperation Association, Jepang. Keranjang Takakura ini dapat menyerap sampah organic suatu keluarga (4-6 anggota keluarga) sampai 1 bulan untuk menjadi penuh dan merubahnya menjadi pupuk kompos. Selain itu kotak ini dapat dipakai berulang-ulang sampai hitungan tahunan untuk menyerap sampah organik skala rumah tangga. ${ }^{30}$

Setiap keluarga pemanfaat pupuk kompos dengan sistem Takakura ini hanya perlu memasukkan sampah rumah tangganya ke dalam keranjang komposter. Sampah rumah tangga yang sebaiknya dikomposkan antara lain: sisa makanan dari meja makan berupa nasi, sayur, kulit buah-buahan. Sisa sayuran mentah dapur berupa akar sayuran dan batang sayuran yang tidak terpakai. Namun, sebelum dimasukkan ke dalam keranjang, sampah harus dipotong-potong kecil sampai ukuran $2 \mathrm{~cm} \times 2 \mathrm{~cm}$. Selanjutnya adalah mengaduk-aduknya setiap selesai memasukkan bahan-bahan yang akan dikomposkan. Jika perlu, boleh ditambahkan selapis kompos yang sudah jadi. Bila kompos sudah berwarna coklat kehitaman dan suhu sama dengan suhu kamar, maka kompos sudah dapat dimanfaatkan.

Dari 456 KK yang ada di kelurahan Wek II Batangtoru, Koperasi Sarop Do Mulana menyalurkan 20 keranjang komposter kepada 20 Kepala Keluarga yang berdomisili di Lorong Garden Kelurahan Wek II Batangtoru. ${ }^{31}$ Penyaluran keranjang komposter tersebut juga disertai dengan penjelasan singkat mengenai cara mengelola pupuk kompos dari sampah organik rumahtangga. Selain itu, anggota koperasi Sarop Do Mulana juga meminta komitmen penerima keranjang komposter untuk

\footnotetext{
${ }^{28}$ Okto Anggara, Ketua Koperasi Sarop Do Mulana, Wawancara, tgl 7 Mei 2018 pukul 21.00 WIB

${ }^{29}$ Okto Anggara, Ketua Koperasi Sarop Do Mulana, Wawancara, tgl 7 Mei 2018 pukul 21.15 WIB

${ }^{30}$ Tim Penulis : Divisi Penulisan \& Multimedia Move Indonesia Divisi Penerbitan dan Dokumentasi Pusat Pendidikan Lingkungan Hidup (PPLH) Seloliman, Ayo Membuat Kompos Takakura (Mojokerto, Pusat Pendidikan Lingkungan Hidup (PPLH) Seloliman, 2007), Hlm. 27

${ }^{31}$ Okto Anggara, Ketua Koperasi Sarop Do Mulana, Wawancara, tgl 15 Januari 2018 pukul 20.30 WIB
} 
memproduksi pupuk kompos tersebut secara berkelanjutan. Masyarakat juga diperbolehkan untuk menjual kembali hasil produksi pupuknya kepada Koperasi Sarop Do Mulana. Berikut ini daftar nama penerima keranjang komposter di Kelurahan Wek II Batangtoru:

Pemberian keranjang komposter oleh Koperasi Sarop Do Mulana kepada Masyarakat Kelurahan Wek II Batangtoru khususnya yang berdomisili di Lorong Garden Kelurahan Wek II Batangtoru bukanlah hal yang serta merta begitu saja dilakukan. Namun hal tersebut merupakan suatu proses yang meliputi langkah demi langkah pertimbangan. Sebagaimana yang dikutip oleh Zubaedi dalam bukunya Pengembangan Masyarakat: Wacana dan Praktik bahwa proses pemberdayaan masyarakat yang digambarkan oleh United Nation meliputi beberapa tahap yaitu: Getting to know the local community, pada tahap ini proses pemberdayaan dimulai dengan mengidentifikasi karateristik masyarakat setempat yang akan diberdayakan, tahap selanjutnya adalah ghatering knowledge about the local community, tahap ini memungkinkan untuk mengumpulkan pengetahuan yang menyangkut informasi mengenai masyarakat setempat. Karakteristik masyarakat Kelurahan Wek II Batangtoru di Lorong Garden didominasi oleh masyarakat bermata pencaharian pedagang, sehingga sampah organik yang dihasilkan cenderung lebih banyak. Selain itu masyarakat di Lorong Garden merupakan masyarakat yang tergolong aktif dalam program-program pemberdayaan. Hal tersebut dapat dilihat dari intensitas masyarakat Keurahan Wek II mengikuti program-program CSR PT. Agincourt Resources. Berikut ini skema pemberdayaan melalui pemberian Fasilitas Berupa Keranjang Komposter Untuk Produksi Pupuk Kompos Skala Rumah Tangga.

Gambar. 3 Skema Pemberian Fasilitas Berupa Keranjang Komposter Untuk Produksi Pupuk Kompos Skala Rumah Tangga

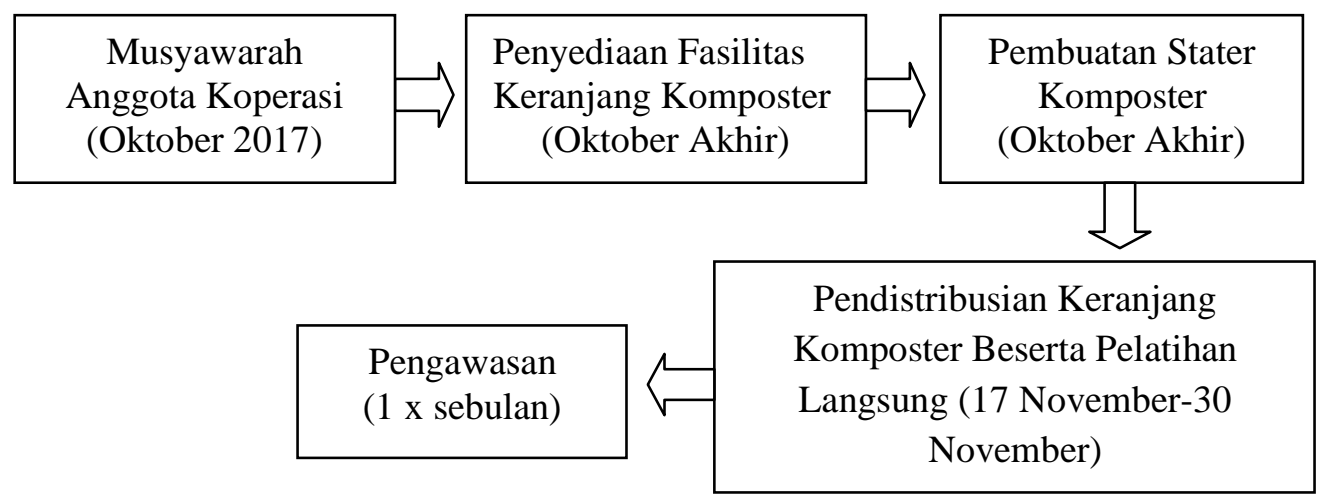

Sumber: Disarikan dari hasil penelitian 2018

2. Ketercapaian Indikator Pemberdayaan dalam Upaya Pemberdayaan Masyarakat melalui Pengelolaan Sampah Organik menjadi Pupuk Kompos oleh Koperasi Sarop Do Mulana Kelurahan Wek II Batangtoru

Indikator keberdayaan masyarakat merupakan parameter yang digunakan dalam mengukur tingkat keberdayaan suatu program. Fungsinya adalah untuk memberi gambaran mengenai akibat langsung dan tidak langsung program pemberdayaan 
masyarakat. ${ }^{32}$ Berikut ini adalah indikator pemberdayaan yang digunakan untuk mengukur ketercapaian keberhasilan pemberdayaan masyarakat melalui pengelolaan sampah menjadi pupuk organik oleh Koperasi Sarop So Mulana Kelurahan Wek II Batangtoru:

\section{a. Tingkat kesadaran dan keinginan untuk berubah (power to)}

Kesadaran dan keinginan untuk berubah (power to) adalah salah satu parameter untuk mengukur derajat keberdayaan masyarakat. Power to dalam Bahasa Indonesia berarti "kekuatan untuk". Parameter ini mengukur kemampuan seseorang dalam bertindak, merangkai ide dari kemampuan yang berasal dari dirinya sendiri. ${ }^{33}$ Kesadaran dan keinginan untuk berubah ini ditandai dengan kemauan masyarakat Kelurahan Wek II Batangtoru untuk menerima program-program pemberdayaan yang diberikan oleh Koperasi SDM. Berikut ini analisis tingkat kesadaran dan keinginan untuk berubah (power to) masyarakat Kelurahan Wek II Batangtoru dari program-program yang telah terlaksana yaitu pemberian fasilitas berupa keranjang komposter untuk produksi pupuk kompos skala rumah tangga.

Masyarakat Kelurahan Wek II merupakan masyarakat yang sebagian besarnya berprofesi sebagai pedagang. Hal ini mengindikasi pengeluaran sampah rumah tanga masyarakatnya lebih banyak dan lebih beragam dari masyarakat lain. Dari 465 Kepala Keluarga di Kelurahan Wek II Batangtoru, sejumlah 20 keluarga bersedia mengelola sampah organik rumah tangganya dengan keranjang komposter Koperasi Sarop Do Mulana. Untuk kelanjutan pengelolaan sampah organik dengan menggunakan keranjang komposter tersebut, telah ada perjanjian secara lisan antara penerima dengan anggota Koperasi Sarop Do Mulana.

Hal ini memang disebabkan terbatasnya keranjang komposter yang tersedia dan juga pertimbangan kriteria penerima keranjang komposter. Masyarakat penerima keranjang komposter ini adalah masyarakat kelurahan Wek II Batangtoru yang memiliki kriteria yang sesuai menurut pengamatan anggota Koperasi Sarop Do Mulana. Diantara kriteria tersebut adalah:

a) Memiliki pekarangan yang dapat dimanfaatkan untuk taman dan kebun minimalis.

b) Jumlah anggota keluarga minimal terdiri dari empat anggota keluarga.

c) Berdomisili di Lorong Garden Kelurahan Wek II Batangtoru

d) Memiliki taman bunga dan kebun minimalis

e) Bersedia memanfaatkan keranjang komposter untuk produksi pupuk skala rumah tangga secara berkelanjutan. ${ }^{34}$

Koperasi Sarop Do Mulana hanya menyalurkan 20 keranjang komposter kepada masyarakat sebagai motivasi bagi masyarakat penerima ataupun masyarakat bukan penerima untuk mengelola sampah rumah tangganya sendiri. Diantaranya masyarakat penerima juga ada yang menolak menerima keranjang komposter tersebut.

Salah seorang anggota koperasi yaitu Siddik Tanjung mengatakan bahwa pemilihan penerima keranjang komposter memang didasarkan atas kriteria

32 Hairi Firmansyah, "Tingkat Keberdayaan Masyarakat dalam Program Pemberdayaan Masyarakat di Kota Banjarmasin dan Kabupaten Tanah Laut”, Jurnal Agribisnis Perdesaan Universitas Lambung Mangkurat, Volume 02, No.1, Maret 2012, Hlm. 57

33 Hairi Firmansyah, "Ketercapaian Indikator Keberdayaan Masyarakat dalam Program Pemberdayaan Fakir Miskin (P2FM) di Kota Banjarmasin”, Jurnal Sosial Ekonomi Pertanian Unlam, Volume 02, No.2, Juni 2012, Hlm. 174

${ }^{34}$ Siddik Tanjung, Bendahara Koperasi Sarop Do Mulana, Wawancara, Tanggal 11 Juni 2018, Pukul 15.10 WIB 
tertentu dan telah ditetapkan berdasarkan hasil musyawarah anggota Koperasi Sarop Do Mulana. Dari daftar penerima yang telah dimusyawarahkan, hanya satu keluarga yang tidak bersedia menerima keranjang komposter dengan alasan keterbatasan waktu dan kesibukan bekerja. ${ }^{35}$

Dari pernyataan tersebut diketahui bahwa dari 20 penerima awal keranjang komposter hanya satu orang saja yang menolak menerimanya. Hal ini menunjukkan tingkat kesadaran dan keinginan untuk berubah (power to) masyarakat Kelurahan Wek II Batangtoru khususnya penerima keranjang komposter jika di persentasekan adalah sebesar $95 \%$.

\section{Grafik. 2 Tingkat Kesadaran dan Keinginan Untuk Berubah (power to) Masyarakat Kelurahan Wek II Batangtoru}

Sadar Kurang Kesadaran

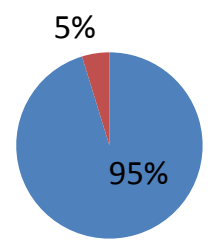

Sumber: Disarikan dari hasil penelitian 2018

\section{b. Tingkat kemampuan meningkatkan kapasitas untuk memperoleh akses (power within)}

Tingkat kemampuan meningkatkan kapasitas untuk memperoleh akses (power within) merupakan harga diri dan martabat individu atau kelompok. ${ }^{36}$ Power within (kekuatan di dalam) ini merupakan kekuatan untuk membayangkan dan membuat harapan. Sehingga di dalam diri individu ada niat, kemauan, kesabaran, semangat, dan kesadaran. ${ }^{37}$ Power within merupakan kemampuan selanjutnya yang harus dimiliki oleh masyarakat setelah power to. Hal ini dapat diukur dari kemauan masyarakat mengaplikasikan dan memelihara program-program pemberdayaan yang telah diterima. Berikut ini adalah analisis tingkat kemampuan meningkatkan kapasitas untuk memperoleh akses (power within) masyarakat kelurahan wek II Batangtoru.

Tingkat kemampuan meningkatkan kapasitas untuk memperoleh akses (power within) dalam program pemberdayaan pemberian fasilitas berupa keranjang komposter ini diukur dari kuantitas produksi pupuk kompos oleh masyarakat. Semakin sering masyarakat memanen pupuk kompos hasil dari pengelolaan sampah organik, maka hal itu semakin menandakan keefektifan program pemberdayaan tersebut terhadap perubahan pola pikir masyarakat dalam mengelola sampah rumahtangganya. Berikut ini adalah data kuantitas produksi sampah organik rumahtangga masyarakat Kelurahan

\footnotetext{
${ }^{35}$ Siddik Tanjung, Anggota Koperasi Sarop Do Mulana, Wawancara, Tanggal 11 Juni 2018, Pukul 14.30 .

${ }^{36} \mathrm{https}: / /$ translate.google.co.id/translate?hl=id\&sl=en\&u=http://www.participatorymethods.org/me thod/power\&prev=search

${ }^{37}$ Ibid.
} 
Wek II Batangtoru dengan menggunakan keranjang komposter Koperasi Sarop Do Mulana mulai dari 17 November 2017 sampai 06 Juli 2018.

Menurut hasil wawancara dengan pengurus koperasi, maksimal masa panen pupuk kompos dalam keranjang komposter adalah satu bulan sekali panen. ${ }^{38}$ Dari pernyataan tersebut, maka maksimal panen dari bulan 17 November 2018 sampai 06 Juli 2018 adalah tujuh kali panen. Penulis menggolongkan tingkat keaktifan masyarakat dalam memproduksi pupuk kompos menjadi empat kategori, yaitu sangat aktif (6-8 kali produksi), aktif (3-5 kali produksi), kurang aktif (1-2 kali produksi) dan pasif (0 produksi).

Data tersebut apabila disajikan dalam diagram grafik adalah sebagai berikut:

\section{Grafik. 3 Tingkat Keaktifan Masyarakat dalam Mengelola Sampah Organik Rumah Tangga Menggunakan Keranjang Komposter Koperasi SDM}

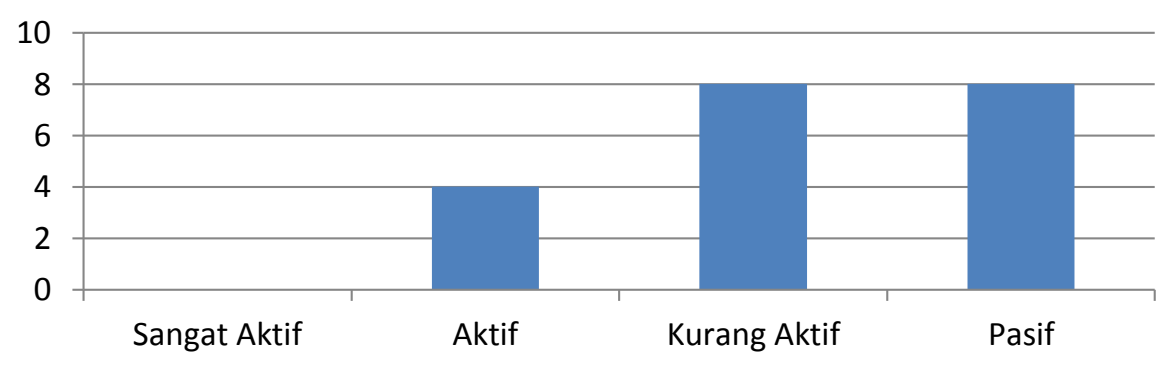

Sumber: Disarikan dari hasil penelitian 2018

Dari grafik tersebut dapat disimpulkan bahwa tingkat kemauan masyarakat penerima dalam mengelola sampah organik rumah tangganya menjadi pupuk kompos dengan menggunakan keranjang komposter Koperasi Sarop Do Mulana masih sangat rendah. Bahkan yang bersikap apatis terhadap program pemberdayaan melalui keranjang komposter masih mendominasi. Hal ini menandakan bahwa tingkat kemampuan meningkatkan kapasitas untuk memperoleh akses (power within) masyarakat Batangtoru juga masih tergolong rendah.

\section{c. Tingkat kemampuan menghadapi hambatan (power over)}

Setiap program pemberdayaan yang diberikan kepada masyarakat tidak akan pernah berjalan dengan sangat mulus. Beberapa hambatan akan dihadapi dalam proses tersebut. Apabila hambatan tidak ditanggulangi, maka akan berpengaruh terhadap pencapaian tujuan pemberdayaan. Berikut ini hambatan yang dihadapi oleh masyarakat penerima program-program pemberdayaan dari Koperasi Sarop Do Mulana.

Dari 20 orang penerima keranjang komposter, 9 orang diantaranya sama sekali tidak pernah memproduksi pupuk dengan menggunakan keranjang komposter tersebut. Dari wawancara yang dilakukan, hambatan yang dihadapi 9 orang penerima keranjang komposter ini terbagi menjadi tiga, yaitu:

a) Kurang pengawasan dari anggota Koperasi Sarop Do Mulana. Salah seorang penerima keranjang komposter yaitu Nauli Hasibuan menyatakan bahwa keranjang tersebut tidak pernah diisi dengan sampah organik rumahtangga sebab tidak ada

${ }^{38}$ Siddik Tanjung, Bendahara Koperasi Sarop Do Mulana, Wawancara, Tanggal 11 Juli 2018, Pukul 20.27 WIB 
dari pihak Koperasi Sarop Do Mulana yang menanyai dan mengawasi keberlanjutan produksi. ${ }^{39}$

b) Kurang pemahaman tentang proses produksi pupuk kompos. Salah seorang penerima keranjang komposter yaitu Rosmaini Harahap mengatakan bahwa tidak pernah dilakukakan pengelolaan sampah organik dengan keranjang komposter sebab kurang paham bagaimana cara pengelolaannya. Sehingga keranjang tersebut dijadikan keranjang sampah biasa. ${ }^{40}$

c) Kurang motivasi dalam mengelola sampah organik rumahtangga sendiri. Salah seorang penerima keranjang komposter yaitu Nisa Gultom mengatakan bahwa salah satu yang menjadikan ia malas mengelolal sampah organik dengan keranjang komposter adalah sebab sampah yang dihasilkan relatif sedikit setiap harinya, sehingga lebih memudahkan untuk membuang sampah di plastik. ${ }^{41}$

Sedangkan masyarakat yang kurang aktif dalam mengelola sampah organik dengan keranjang komposter berjumlah 7 keluarga. Beberapa hambatan yang dihadapi masyarakat yanng tergolong kurang aktif mengelola sampah organik tersebut selain yang telah disebutkan diatas yaitu:

a) Kehabisan bahan-bahan stater pupuk kompos. Salah seorang penerima keranjang komposter yaitu Helmi Ritonga mengatakan bahwa sebab ia berhenti mengelola pupuk organik dengan keranjang komposter adalah sebab bahan-bahan stater pupuk dalam keranjang tersebut telah habis, sehingga harus dicari dan dibuat kembali. ${ }^{42}$

b) Keranjang komposter mengundang serangga-serangga kecil yang mengganggu. Salah seorang penerima keranjang komposter bernama Rengki Saputra mengatakan bahwa keranjang komposter tersebut mengundang banyak semut sehingga mengganggu ketenangan dan kebersihan di teras rumah. ${ }^{43}$

Tingkat kemampuan menghadapi hambatan (power over) masyarakat penerima keranjang komposter di Kelurahan Wek II Batangtoru tergolong rendah sebab berdasarkan wawancara dan observasi peneliti, dari 20 orang yang menerima keranjang komposter hanya enam keluarga yang masih menggunakan keranjang komposter untuk mengelola sampah organik, yaitu Siddik Tanjung, Ratna Sihombing, Ernawati Lubis, Asnawati Koto, Okto Anggara dan Ratna Sitopul. Selain dari itu, masyarakat penerima keranjang komposter telah mengalihgunakan fungsi komposter tersebut. Dalam tabel berikut ini dijelaskan pengalihgunaan keranjang komposter oleh masyarakat penerima keranjang komposter Koperasi Sarop Do Mulana.

\section{d. Tingkat kemampuan kerjasama dan solidaritas (power with)}

\footnotetext{
${ }^{39}$ Nauli Hasibuan, Masyarakat Penerima Keranjang Komposter Koperasi Sarop Do Mulana, Wawancara, Tanggal 05 Juli 2018, Pukul. 16.50 WIB

${ }^{40}$ Rosmaini Harahap, Masyarakat Penerima Keranjang Komposter Koperasi Sarop Do Mulana, Wawancara, Tanggal 24 Juni 2018, Pukul 15.20 WIB

${ }^{41}$ Nisa Gultom, Masyarakat Penerima Keranjang Komposter Koperasi Sarop Do Mulana, Wawancara, Tanggal 05 Juli 2018, Pukul 11.20 WIB

${ }^{42}$ Helmi Ritonga, Masyarakat Penerima Keranjang Komposter Koperasi Sarop Do Mulana, Wawancara,Tanggal 24 Juni 2018, Pukul 14.40 WIB

${ }^{43}$ Rengki Saputra, Masyarakat Penerima Keranjang Komposter Koperasi Sarop Do Mulana, Wawancara, Tanggal 05 Juli 2018, Pukul 17.10 WIB
} 
Power With (kekuatan dengan) merupakan tindakan bersama, kemampuan untuk bertindak bersama. Dasarnya saling mendukung, solidaritas dan kerjasama.. ${ }^{44}$ Tingkat kemampuan kerjasama dan solidaritas (power with) merupakan derajad keberdayaan masyarakat tertinggi. Saat masyarakat penerima program pemberdayaan telah berhasil mengembangkan dan membangun kerjasama dengan pihak lain, hal tersebut bisa mengindikasikan keberhasilan program pemberdayaan. Dari program-program pemberdayaan Koperasi Sarop Do Mulana, salah satu penerima program pemberdayaan yang termasuk memiliki tingkat kerjasama dan solidaritas yang lebih adalah Maulini Matondang. Keranjang Komposter dan Pertanian teknik Hidroponik dan Akuaponiknya dipakai oleh Koperasi Sarop Do Mulana untuk dipajang dalam Karnaval Pertanian 5 Desember 2018 di Aekpining, Batangtoru. ${ }^{45}$

\section{Penutup}

Berdasarkan penelitian yang telah dilakukan, penulis menyimpulkan bahwa:

1. Bentuk-bentuk pemberdayaan masyarakat melalui pengelolaan pupuk kompos oleh koperasi Sarop Do Mulana adalah berupa pemberian fasilitas keranjang komposter untuk produksi pupuk kompos skala rumah tangga.

2. Ketercapaian indikator pemberdayaan dalam program pemberian fasilitas berupa keranjang komposter untuk produksi pupuk kompos skala rumah tangga oleh Koperasi Sarop Do Mulana tidak tercapai sebab dari keempat parameter keberdayaan masyarakat hanya indikator tingkat kesadaran dan keinginan untuk berubah (power to) yang masuk kategori tinggi.

3. Faktor penghambat program pemberdayaan masyarakat melalui pemberian fasilitas berupa keranjang komposter untuk produksi pupuk kompos skala rumah tangga oleh Koperasi Sarop Do Mulana adalah: kurang pengawasan dari anggota koperasi sarop do mulana, kurang pemahaman tentang proses produksi pupuk kompos dan kurangnya motivasi dalam mengelola sampah organik rumahtangga sendiri.

\section{DAFTAR KEPUSTAKAAN}

Aprillia Theresia, dkk, Pembangunan Berbasis Masyarakat, Bandung: Alfabeta, 2014. Bungin, Burhan, Analisis Data Penelitian Kualitatif, Jakarta: Raja Grafindo Persada, 2003.

Firmansyah, Hairi "Ketercapaian Indikator Keberdayaan Masyarakat dalam Program Pemberdayaan Fakir Miskin (P2FM) di kota Banjarmasin", Jurnal Agribisnis Perdesaan Vol. 2, No.2, Juni 2012. , "Tingkat Keberdayaan Masyarakat dalam Program Pemberdayaan

Masyarakat di Kota Banjarmasin dan Kabupaten Tanah Laut", Jurnal Agribisnis Perdesaan Universitas Lambung Mangkurat, Volume 02, No.1, Maret 2012.

Hadisuwito, Sukamto, Membuat Pupuk Organik Cair, Jakarta: PT AgroMedia Pustaka, 2012.

Dianto, Icol. "PEMBERDAYAAN KELOMPOK USAHA PENINGKATAN PENDAPATAN KELUARGA SEJAHTERA (UPPKS) DALAM MENINGKATKAN KESEJAHTERAAN KELUARGA DI PASAMAN.” Jurnal

\footnotetext{
${ }^{44}$ digilib.uinsby.ac.id/402/5/Bab\%202.pdf

${ }^{45}$ Maulini Matondang, Masyarakat Penerima Pelatihan Pertanian dengan Teknik Hidroponik dan Akuaponik dan Keranjang Komposter, Wawancara, Tanggal 05 Juli 2018, Pukul 16.50 WIB
} 
Hikmah 10, no. 1 (2016): 122.

Lexy J. Meleong, Metodologi Penelitian Kualitatif, Bandung: PT Remaja Rosdakarya, 2008 .

M. Anwas, Oos, Pemberdayaan Masyarakat di Era Global, Bandung: Alfabeta, 2014.

Machedrawaty, Nanih \& Agus Safei, Pengembangan Masyarakat Islam dari Ideologi, Strategi sampai Tradisi, Bandung: PT Remaja Rosdakarya, 2001.

Mardikanto, Totok \& Poerwoko Soebiato, Pemberdayaan Masyarakat Dalam Perspektif Kebijakan Publik, Bandung: Alfabeta, 2013.

Margono, Metodologi Penelitian Pendidikan, Jakarta: PT Rhineka Cipta, 2004.

Pachta, Andjar W. dkk, Hukum Koperasi Indonesia, Jakarta: Kencana Prenada Media Grup, 2005.

Silvia, Reni Nasution, "Berbagai Cara Penanggulangan Limbah", Journal of Islamic Science and Technology Vol. 1, No.1, Juni 2015.

Sumantri, Arif, Kesehatan Lingkungan, Jakarta: Kencana Prenada Media Grup, 2010.

Soerkoyo, Hery, Kiat Pintar Memproduksi Kompos dengan Pengurai Buatan Sendiri, Yogyakarta: Lily Publisher, 2011.

Soetomo, Pemberdayaan Masyarakat, Mungkinkah Muncul Antitesisnya?, Yogyakarta: Pustaka Pelajar, 2011

Soleh, Chabib, Dialektika Pembangunan dengan Pemberdayaan, Bandung: Fokus Media, 2014

Sulistiyani \& Ambar Teguh, Kemitraan dan Model-Model Pemberdayaan, Yogyakarta: Gava Media, 2004.

Republik Indonesia, 1992, “Undang-Undang No.25 Tahun 1992 tentang Perkoperasian".

Ryadi, Slamet, Kesehatan Lingkungan, Surabaya: Karya Anda, 1984

Tatan Hermansah, dkk, Dasar-dasar Pengembangan Masyarakat Islam, Jakarta: Fakultas Ilmu Dakwah dan Komunikasi UIN Syarif Hidayatullah, 2009.

Tim Penulis : Divisi Penulisan \& Multimedia Move Indonesia Divisi Penerbitan dan Dokumentasi Pusat Pendidikan Lingkungan Hidup (PPLH) Seloliman, Ayo Membuat Kompos Takakura, Mojokerto, Pusat Pendidikan Lingkungan Hidup (PPLH) Seloliman, 2007.

Yulistiani, Indriyani, Ragam Penelitian Kualitatif: Penelitian Lapangan, Fakultas Ilmu Sosial dan Ilmu Politik: UI, 2001

Zubaedi, Pengembangan Masyarakat: Wacana dan Praktik, Jakarta: Prenadamedia Grup, 2013.

Zuriah, Nurul, Metodologi Penelitian Sosial dan Pendidikan Teori-Aplikasi, Jakarta: Bumi Aksara, 2007.

http://nasional.republika.co.id/berita/nasional/daerah/17/03/15/omv2sg319-setiap-hariindonesia-produksi-sampah-65-juta-ton.

https://geotimes.co.id/arsip/2019-produksi-sampah-di-indonesia-671-juta-ton-sampahper-tahun/

http://www.menlh.go.id/DATA/UU18-2008.pdf

http://ppsp.nawasis.info/dokumen/perencanaan/sanitasi/pokja/ssk/kab.tapanuliselatan/D ok.Final\%20SSK.pdf

http://tapanuliselatankab.bps.go.id/

digilib.uinsby.ac.id/402/5/Bab\%202.pdf

https://translate.google.co.id/translate?hl=id\&sl=en\&u=http://www.participatorymethod s.org/method/power\&prev=search 
Ibnu Abbas, Pandangan Syariah Dalam Pengelolaan Sampah, https://ibnuabbaskendari.wordpress.com/2011/02/20/pandangan-syariah-dalam pengelolaan asampah. html. 